\title{
プラズマと光励起プロセス
}

\author{
広 瀬 全 孝 \\ 広島大学工学部 $\overline{\mathbf{T}} 724$ 東広島市西条町下見 \\ (1984 年10月 9 日 受理)
}

\section{Plasma and Photo-excited Processes}

\author{
Masataka HIROSE \\ Faculty of Engineering, Hiroshima University \\ Saijoh-cho, Higashihiroshima 724
}

(Received Octorber 9, 1984)

\begin{abstract}
Recent progress in materials processing by using reactive plasma or photochemical technique is reviewed. The characteristic features of both techniques are discussed in terms of chemical reactions which proceed in the plasma or under photoirradiation.
\end{abstract}

\section{1. はじめに}

プラズマ中での化学反応を利用したエッチング技術や 薄膜形成（プラズマCVD）法は, 今日, 超 LSI プロセ ス技術として重要な位置を占めている(1,2)。また, プラ ズマ CVD 法で作製される半導体薄膜（典型的にはアモ ルファスシリコン) は, そのデバイス応用が急ピッチで 進んでいる。またダイアモンド状カーボン膜の形成や各 種有機薄膜の研究も進んでいる。これら反応性ガスのグ ロー放電プラズマ中では，(1)低い温度で高効率に反応 が起る，(2)電子，イオン，中性分子種から成る非平衡 条件下で化学反応が進む，などの特徵をあつ。このよう に, 通常の熱反応とは異る化学プロセスを利用している だけに，プラズマ中の中性化学活性種（原子, 解離生成 種を含めてラジカルと総称する) やイオン種をうまく使 いわけて, 新規性のある応用技術が次々と開発されて来 た。一方, 紫外光照射下で起る, 反応性ガスの光化学分 解を用いた薄膜形成 (光 CVD) 法やエッチング技術は, この $2 \sim 3$ 年急速にその研究が盛んになって来た新技術 である。低圧水銀ランプや $\mathrm{Xe}-\mathrm{Hg}$ ランプによる紫外光 やエキシマレーザ光を光源として用いる光プロセス技術 の開発が盛んである ${ }^{3)}$ 。フォトンによるガスの直接分解 反応は本質的に低温プロセスであり, 反応系にイオンや 電子を殆んど含まない点でプラズマプロセスとは大きな ちがいを有している。本稿では，てれら2つのプロセス 技術の現状をレビューすると共に, 将来展望についてあ 私見を述べたい。また，プラズマや光の関与する化学反
応は気相反応と固体表面での反応のいずれもが関与して おり,てれらの反応素過程についての研究にも触れたい。

\section{2. プラズマ反応と光化学反応}

プラズマ中で起る化学反応は, 電界で加速された電子 がガス分子に衝突して起る励起, 解離, 電離などの過程 を経由する。Fig. 1 ( a ) 亿示すような平行平板型電極間 に高周波電圧を印加して, 励起されたプラズマにおいて は, 電極近傍にイオンシースが形成され (Fig. 1(b)), ここでの平均電位降下は電極面積の非対称性によって近 似的に決まる。パワー電極の面積 $A_{1}$, シース電位降下 $V_{1}$, 接地電極の実効面積 (これは接地されている容器の 壁の寄与む含む) $A_{2}$, 電位降下 $V_{2}$ とすると, 静電的な 電荷保存の条件から, 近似的に次の式が成り立つ。

$$
A_{1} V_{1}=A_{2} V_{2}
$$

Fig. 1 (b)から明らかなように，プラズマポテンシャル (常に正) $V_{P}=V_{2}, V_{1}=V_{P}+V_{L C}\left(A_{1}<A_{2}\right.$ なら $\left.V_{D C}<0\right)$ となっている4)。

陽光柱領域には, ラジカル, イオン, 電子が共存し, ほぼ電荷中性条件を満足している。通常のグロー放電中 の荷電粒子密度は中性粒子密度に較べて数析低い低電離 プラズマである。陽光柱内のラジカル（イオンより圧倒 的に多い引は電極に向かって拡散し，基板上に吸着する。 CVD の場合は接地電極上におかれた基板上での表面反 応を経て薄膜が形成される4)。エッチングの場合はパワ 一電極上におかれた基板表面を反応種が攻撃する。CVD の場合にも基板表面は正のプラズマ電位のためにイオン 
種による衝撃を受ける。エッチングの場合には，ラジカ ルによる表面反応のみでは等方的なエッチングしかでき ないが負の自己バイアス $V_{D C}$ による加速イオンの衝撃 をうまく制御すると，異方性の高いエッチングが可能に なる5。

次に, 光化学反応について考えてみよう。ガス分子に UV 光（エキシマレーザ光，低压水銀ランプ光など）が 照射されると，分子は光吸収によって電子励起され，場 合によっては光分解与る。光分解過程は Fig. 2(a)に 示すように分子が直接解離ポテンシャルへ励起され分解 する直接解離と，Fig. 2(b)のように一度安定な結合ポ テンシャルに励起されて後に解離ポテンシャルへ移行し て分解する前期解離がある。前者の励起状態の寿命は分 子の振動周期の半分で極めて短く $\left(<10^{-12} \mathrm{sec}\right)$, 光吸収 スペクトルはブロードとなる。後者では, 解離ポテンシ ヤルに移るのに時間を要するので寿命はやや長くなる。 また励起状態での分子の回転・振動状態に関係して光吸 収に微細瞄造え゙現われる。また，励起エネルギーが小さ い上解離ポテンシャルへ移ることができず光分解しな い。したがって反応性ガスの光吸収スペクトル薙れ ば，与えられた波長領域で光分解するかどうかおる程度 判定できる。

ガス相の兑励起によって生じた分解種又は励跑央（こ こでは単に反応種という）は基板に吸着する。吸誉確率 は光入射法によって異なる。Fig. 3（a）のような瑂直入 射の場合には，ガス相の励起によって生じた化学種の種 類, 励起状態以外に, 基板の励起状態が関係してくる。 吸着した反応種方光励起されると吸着種間, 吸着䨪之基 板間の相互作用が促進されるし，同時に吸着種の離脱も 起り易くなる(Fig. 3(c))。図(b)のような平行入射法

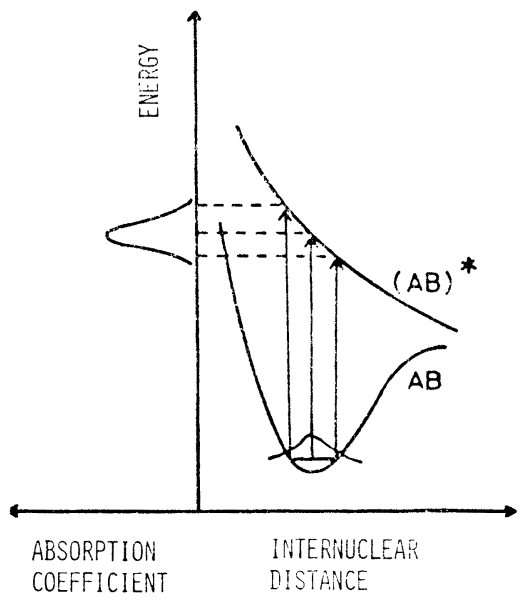

(a)

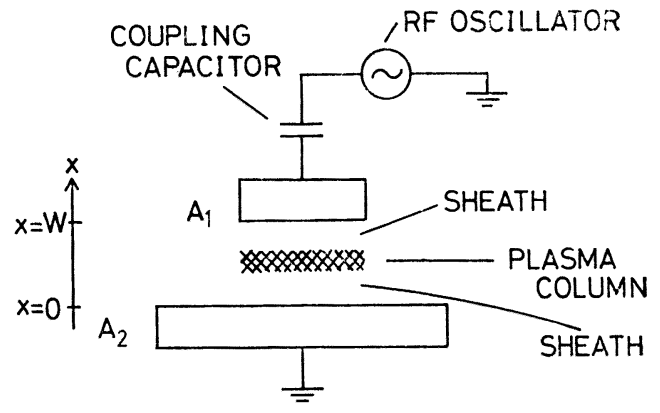

(a)

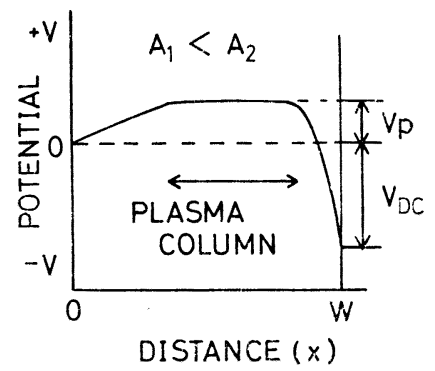

(b)

Fig. 1 (a) Schematic diagram of discharge system.

(b) Average potential distribution between electrodes (in the case of $\mathrm{A}_{1}<\mathrm{A}_{2}$ ).

では基板の光励起は重要でなく，(a )，（b )のような配 置で基板の光励起の効果を知ることができる。

Fig. 3(d)の例のように基板の光励起及び加熱によっ ても基板とガスとの表面反応及び吸着種の脱離が起乙 る。固体の場合は, ガス原子や分子の場合と翼なり, 光

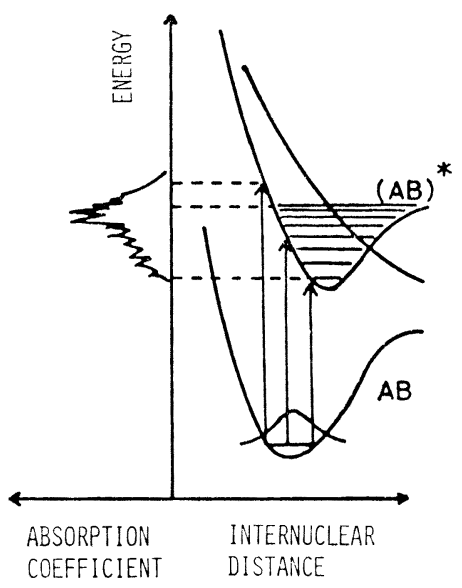

(b)

Fig. 2 Light abscrption through (a) direct dissociation or (b) predissociation. 
Table 1 Comparison between plasma and photoexcited processes

\begin{tabular}{lll}
\hline & \multicolumn{1}{c}{ Plasma } & Photo \\
\hline Excitation Process & molecule-electron collision & molecule-photon collision \\
\hline $\begin{array}{l}\text { Energy Distribution of } \\
\text { Excitation Source }\end{array}$ & $\begin{array}{l}\text { broad (monochromatic energy is } \\
\text { impossible) }\end{array}$ & $\begin{array}{l}\text { energy spectrum of light source } \\
\text { (monochromatic energy is possible) }\end{array}$ \\
\hline $\begin{array}{l}\text { Reaction Species } \\
\text { ground state and excited state radicals } \\
\text { and ions }\end{array}$ & $\begin{array}{l}\text { ground state radicals (ions for high } \\
\text { energy photons) }\end{array}$ \\
\hline $\begin{array}{l}\text { Velocity of Incident } \\
\text { Molecule }\end{array}$ & $\begin{array}{l}\text { self-bias for ion, thermal velocity for } \\
\text { radicals }\end{array}$ & thermal velocity \\
\hline $\begin{array}{l}\text { Elementary Reaction } \\
\text { Process }\end{array}$ & $\begin{array}{l}\text { complicated (in gas phase and on } \\
\text { surface) surface is ion-bombarded }\end{array}$ & $\begin{array}{l}\text { a few reaction branching, and no } \\
\text { surface ion damage }\end{array}$ \\
\hline Controllability & parameters mutually dependent & $\begin{array}{l}\text { possible by tuning wavelength and } \\
\text { intensity of the light }\end{array}$ \\
\hline Reaction Selectivity & no & yes
\end{tabular}

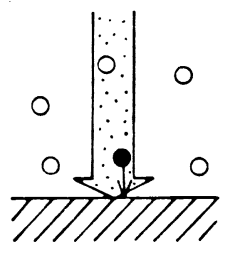

(a)

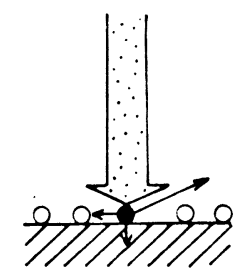

(c)

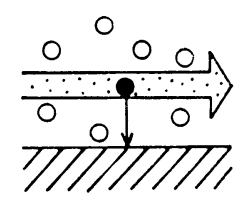

(b)

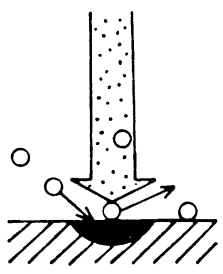

(d)
Fig. 3 Chemisorption process of photo-excited species (solid circles) for (a) vertical and (b) parallel light incident to the sample surface. Resonant excitation of the adsorbate may promote adsorbate-adsorbate and adsorbate-adsorbent interaction as well as well as molecular desorption (c). Direct laser excitation and heating of the substrate may also induce surface reaction and desorption (d).

吸収係数は，広い波長範囲にわたって大きい。レーザ光 と固体との相互作用は, 赤外又は遠赤外での直接格子振 動励起を除いて, ほとんどの場合, その固体中の電子と の間で起こる。光子吸収の結果, バンド間励起, バンド 内励起, 及び自由電子の励起が起る。電子に吸收された
エネルギーは最終的には固体原子に分配され格子振動 （熱）となる。励起された電子系のエネルギーが格子振 動を励起するに要する時間 $\tau_{\mathrm{e}-\mathrm{phon}}$ は $10^{-11} \mathrm{sec}$ 程度であ る。一方吸着種と基板の反応時間 $\tau_{\mathrm{ads}-\mathrm{s}}$ は $10^{-9} \sim 10^{-12}$ $\sec$ であり, $\tau_{\mathrm{e}-\mathrm{phon}}>\tau_{\mathrm{ads}-\mathrm{s}}$ の条件が満されるとき, 基 板との反応は非熱的なむのとなる3)。Table 1 はプラズ マプロセスと光励起化学反応の特徴を比較したもので両 者のちがいが多岐にわたることが理解できる。

\section{3. プラズマ CVD}

プラズマ反応を用いる薄膜形成技術は, 半導体プロセ スにおいて $\mathrm{Si}_{3} \mathrm{~N}_{4}$ の形成にも用いられており, $\mathrm{SiO}_{2}$, PSG 膜の利用も検討されている22。アモルファスシリコ ン薄膜屯太陽電池, 薄膜トランジスタ, フォトリセプタ 一などへの応用が盛んである6)。ダイアモンド状カーボ ン膜"), 電子線レジスト膜などの有機薄膜 ${ }^{2}$ の形成にも 利用されている。

ここでは, 半導体用無機薄膜として $\mathrm{Si}, \mathrm{Si}_{3} \mathrm{~N}_{4}$ 膜の形 成プロセスを中心に話を進める ${ }^{8)}$ 。

プラズマ中の電子のエネルギ分布は $2 \sim 3 \mathrm{eV}$ にピーク を持ち $10 \mathrm{eV}$ 以上まですそを引いているので大部分のガ ス分子は一電子衝突で解離される。解離のしきいエネル ギの目安はガス分子の光化学分解のしきいエネルギ程度 であるから, $\mathrm{SiH}_{4}$ ガスで 7 $8 \mathrm{eV}, \mathrm{Si}_{2} \mathrm{H}_{6}$ で $6 \mathrm{eV}, \mathrm{NH}_{3}$ で $6 \mathrm{eV}$ 程度である。高エネルギ電子の衝突では, 殆ん どあらゆる種類のラジカルが形成され $\mathrm{SiH}_{4}$ では次の反 応が全て起る。

$$
\mathrm{SiH}_{4} \longrightarrow \mathrm{Si}+2 \mathrm{H}_{2}
$$




$$
\begin{aligned}
& \mathrm{SiH}_{4} \longrightarrow \mathrm{SiH}+\mathrm{H}_{2}+\mathrm{H} \\
& \mathrm{SiH}_{4} \longrightarrow \mathrm{SiH}_{2}+\mathrm{H}_{2} \\
& \mathrm{SiH}_{4} \longrightarrow \mathrm{SiH}_{3}+\mathrm{H}
\end{aligned}
$$

表面科学 第 5 巻 第 4 号 (1984)

$\mathrm{NH}_{3}$ でも同様に, $\mathrm{N}, \mathrm{N}_{2}, \mathrm{NH}, \mathrm{NH}_{2}, \mathrm{H}, \mathrm{H}_{2}$ などの解離 生成物を生ずる。勿論解離生成物のうち 2 原子分子や原 子は発光準位に電子励起される確率も高く, $\mathrm{SiH}, \mathrm{Si}, \mathrm{H}$, $\mathrm{H}_{2}, \mathrm{~N}, \mathrm{~N}_{2}, \mathrm{NH}$ などの種は発光性である。従ってプラ ズマ中の化学的活性種濃度のモニタとしてラジカルの発 光強度を利用することができる。 $\mathrm{SiH}_{n}(n=0,1, \cdots, 3)$ ラ ジカルのイオン化エネルギは 7.4〜9.5 eV の領域にある が, $\mathrm{SiH}_{4}$ から直接 $\mathrm{SiH}_{n}{ }^{+}$イオンを生成するしきいエネ ルギは $12 \mathrm{eV}$ 以上である ${ }^{4}$ 。従って，イオン種濃度はラ ジカル濃度に比べて大幅に少いが，CVD で通常使われ る圧力領域 0.1 T Torr では分子の平均自由行程が短い ため, イオン・分子反応やラジカル・分子反応も重要で, 例えば次のような反応が知られている。

$$
\begin{aligned}
& \mathrm{SiH}_{2}^{+}+\mathrm{SiH}_{4} \longrightarrow \mathrm{SiH}_{3}^{+}+\mathrm{SiH}_{3} \\
& \mathrm{H}+\mathrm{SiH}_{4} \longrightarrow \mathrm{SiH}_{3}+\mathrm{H}_{2}
\end{aligned}
$$

以上のことから分るようにプラズマによる分子の化学 分解は, 多岐にわたる解離反応を経由するばかりでな く, 未分解分子とイオン, ラジカルとの副次的な反応む 盛んに起るために気相反応を単純化したモデルでとらえ ることがむずかしい。この点は後述する光化学反応と大 きくちがう。しかし，気相の状態を質量分析法や発光分 光分析法で規定し，乙の結果と薄膜の成長速度，組成な どとの対応関係の追跡から，薄膜成長過程のモデルを導 くことはある程度可能である2.4.8)。

詳細な議論は原論文にゆずるが， $\mathrm{SiH}_{4}$ プラズマから の $\mathrm{Si}$ 薄膜の形成過程における基板表面反応のモデルは,

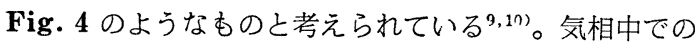
膜形成の前駆物質を $\mathrm{SiH}_{2}$ と考える Kampas らのモデル は成長表面での $\mathrm{SiH}_{2}$ 分子の $\mathrm{SiH}$ 結合への挿入反応を 仮定し，図の左上から右に向う径路で成長過程を説明す るが，筆者らは，気相中の $\mathrm{SiH} と \mathrm{H}$ を前駆物質と考え 左下から右に向う表面反応を考えた。つまり，Kampas らは気相中から成長表面に吸着した $\mathrm{SiH}_{2}$ 分子 (図左上) が成長表面の $\mathrm{SiH}$ 結合に挿入反応で割り込み $\mathrm{SiH}_{3}$ 結 合を形成し (図右上), 然る後に $\mathrm{SiH}_{3}$ 結合加ら $\mathrm{H}_{2}$ 分 子を放出し（図中段右）膜形成が進むと考えた。筆者ら は成長表面に吸着した $\mathrm{SiH}$ 分子が成長表面の $\mathrm{SiH}$ 結合 に割り込み $\mathrm{SiH}_{2}$ 結合を作り (罒右下), この $\mathrm{SiH}_{2}$ 結合 の 1 つの $\mathrm{H}$ 原子を気相中の $\mathrm{H}$ 原子がスカベンジし $\mathrm{H}_{2}$ 分 子として除去すると考えた。

いづれのモデルでも, 成長温度が低い $\left(<400^{\circ} \mathrm{C}\right)$ ため にシリコン薄膜中に含まれる水素含有量の基板温度依存 性をうまく説明できる。後者のモデルでは更にプラズマ
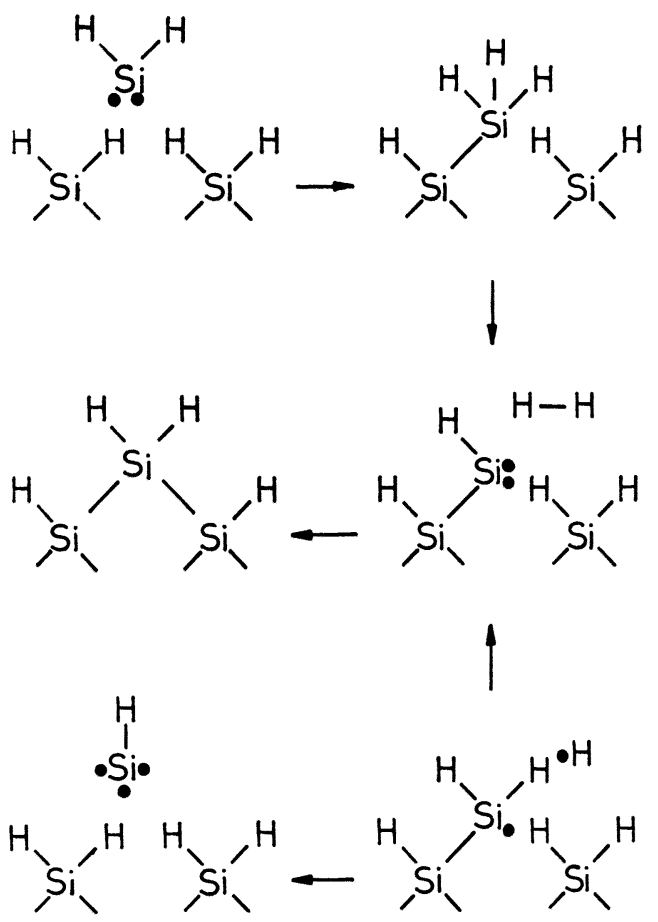

Fig. 4 Growth model of $\mathrm{Si}$ from $\mathrm{SiH}_{4}$ plasma.

中の発光性 $\mathrm{SiH}, \mathrm{H}$ ラジカル濃度の積が膜成長速度と良 い相関を示すととも説明できている。これと，同様なモ デルによって, $\mathrm{SiH}_{4}+\mathrm{NH}_{3}$ プラズマからの $\mathrm{Si}_{3} \mathrm{~N}_{4}$ 膜の 成長機構屯うまく説明できる11)。

プラズマ CVD 技術は, 現状ではまだ十分に化学とし ての基礎が固まっていない。また，与えられた電子エネ ルギ分布に対して，いつあ最適の反応ガスを選んでいる とは限らない。この点についてむ化学の側からのアプロ 一チが必要と考える。

\section{4. プラズマエッチング}

固体材料のエッチングは，エッチングガス $\mathrm{AB}$ の放電 解離生成種と固体表面 C との次の様な反応を前提として いる。

$$
\begin{aligned}
& \mathrm{AB} \rightleftarrows \mathrm{A}+\mathrm{B} \\
& \mathrm{A}+\mathrm{B}+\mathrm{C}(\mathrm{s}) \rightleftarrows \mathrm{AC}(\mathrm{g})+\mathrm{B}
\end{aligned}
$$

エッチング種 $\mathrm{A}$ の再結合による消滅を抑えるには (8), (9) 式の逆反応に関与する生成種 Bを効率よく他の安定 分子に転換できるようにガス Dを加える。すなわち

$$
\mathrm{B}+\mathrm{D} \longrightarrow \mathrm{BD}(\mathrm{g})
$$

例えば， $\mathrm{CF}_{4}$ プラズマによる多結晶 $\mathrm{Si}$ のエッチングに おいてはエッチング種である Fラジカルは主に次の反応 で生成される。

$$
\mathrm{CF}_{4} \longrightarrow \mathrm{CF}_{3}+\mathrm{F}
$$




$$
\mathrm{CF}_{4} \longrightarrow \mathrm{CF}_{3}{ }^{+}+\mathrm{F}+\mathrm{e}
$$

勿論その他の $\mathrm{CF}_{m}(m=0,1, \cdots, 3)$ ラジカル及びイオン 屯同時に生成される。上の反応で作られるFラジカルは $\mathrm{CF}_{3}$ との再結合で容易に失われ,

$$
\mathrm{CF}_{3}+\mathrm{CF}_{3} \longrightarrow \mathrm{C}_{2} \mathrm{~F}_{6}
$$

のような反応で(11)式から F が遊離される割合程度しか 活性種が作られない。そこで（10）の反応を用いて， $\mathrm{CF}_{3}$ ラジカルを効果的に除去するために添加ガス Dとして $\mathrm{O}_{2}$ を加えると

$$
\mathrm{CF}_{3}+\mathrm{O} \longrightarrow \mathrm{COF}_{2}+\mathrm{F}
$$

の反応によって効率よくFラジカルが生成される。結局 Si のエッチングは次のように起る。

$$
\mathrm{Si}(\mathrm{s})+4 \mathrm{~F}(\mathrm{~g}) \longrightarrow \mathrm{SiF}_{4}(\mathrm{~g})
$$

このエッチングは $\mathrm{O}_{2}$ 添加による長寿命ラジカルを用い た等方的な反応である ${ }^{12,13)}$ 。

パワー電極上に基板を置いて，シース領域のセルフバ イアス $V_{D C}$ 下で垂直入射してくるイオンの照射効果を うまく利用すれば照射面上での化学反応は増速され，側 壁にはこの効果がないので，異方性の高い，いわゆる反 応性イオンエッチング (RIE) が可能となる。との分野 は半導体集積回路プロセスの最前線にあって, います精 力的な研究が進められている。文献 $1 ， 2 ， 5$ には詳しい 解説があるので参照されたい。

\section{5. 光励起プロセス}

超高密度集積回路においては，乙れまで使われて来 た，反応性イオンエッチングやプラズマ CVD などのプ ラズマプロセスを使うことに危惧の念が持たれている。 これはプラズマ中の高エネルギ粒子による照射損傷の問 題があるからである。最近光励起プロセスが急速に注目 されるようになったのは，CVD，エッチングなどを低温 低損傷で実現できるととと，選択 CVD, レジストレス エッチング, 光エピタキシなどの可能性が示されている からである(4)。

光化学反応では気相中の分子を電子励起することによ って解離させるので, その素過程は比較的良く調べられ ている。また反応性ガスの光吸収端も分っている場合が 多いので, 適切な光源を選べば気相反応の道筋を予测す ることがある程度可能である。しかし，エッチングや CVD においては，活性種の表面反応が律速過程となる 場合屯多いので, オーバーオールの光化学反応を正しく 理解することは必ずしも容易ではない。

\section{1 光 CVD}

最初に Si の薄膜形成について述べよう。 $\mathrm{SiH}_{4}$ ガスの 光吸収端は $160 \mathrm{~nm}$ と短かく, 1 光子過程で直接光化学 分解するのに適切な光源がない。従って筆者らは $\mathrm{Si}_{2} \mathrm{H}_{6}$
の光吸収端が $200 \mathrm{~nm}$ と長く, 低圧水銀ランプ $(185 \mathrm{~nm})$ によって直接光分解できるととに着目し, シリコン薄膜 の形成を行った ${ }^{15)}$ 。また $\mathrm{PH}_{3}$ (吸収端 $200 \mathrm{~nm}$ )， $\mathrm{B}_{2} \mathrm{H}_{6}$ (吸収端 $200 \mathrm{~nm}$ ) を添加するととにより $\mathrm{n}$ 型膜, $\mathrm{p}$ 型膜 が形成できることを明らかにした ${ }^{16)} 。 \mathrm{Si}_{2} \mathrm{H}_{6}$ 解離の主反 応は

$$
\mathrm{Si}_{2} \mathrm{H}_{6}+\mathrm{h} \nu \longrightarrow \mathrm{SiH}_{2}+\mathrm{SiH}_{3}+\mathrm{H}
$$

と考えられる ${ }^{17)}$ 。

成長表面の吸着した $\mathrm{SiH}_{2}$ ラジカルは水素ラジカルに よる引き抜き反応によって固体 $\mathrm{Si}$ を析出すると考えら れる。

$$
\mathrm{SiH}_{2}+2 \mathrm{H} \longrightarrow \mathrm{Si}(\mathrm{s})+2 \mathrm{H}_{2}(\mathrm{~g})(\Delta H=-2.37 \mathrm{eV})
$$

この反応は exothermic で十分早いと考えられるの で, 膜の成長速度は基板温度に依存せず気相での $\mathrm{Si}_{2} \mathrm{H}_{6}$ の解離速度によって律速される。実際, 成長速度はFig. 5 に示すように入射光強度に比例して増加しており，1 光子吸収による直接光分解反応であることが示されてい る。乙れを更に裏付けているのが Fig. 6 である。 $\mathrm{Si}_{2} \mathrm{H}_{6}$ 濃度の増大による成長速度の低下は, 光分解活性種 $\left(\mathrm{SiH}_{2}\right.$ など）が基板上へ拡散する過程で未分解 $\mathrm{Si}_{2} \mathrm{H}_{6}$ との衝突 が多いと, $\mathrm{Si}_{3} \mathrm{H}_{8}$ のような高次安定分子となり基板には 付着しないととを示している。シリコンへの不純物添加 は, $\mathrm{Si}_{2} \mathrm{H}_{6}, \mathrm{PH}_{3}, \mathrm{~B}_{2} \mathrm{H}_{6}$ の光吸収断面積が $190 \sim 200 \mathrm{~nm}$ で，それぞれ $7 \times 10^{-18} \sim 4 \times 10^{-19}, 2 \times 10^{-17} \sim 5 \times 10^{-18}, 3$ $\times 10^{-19} \sim 6 \times 10^{-20} \mathrm{~cm}^{2}$ であるととから ${ }^{18,19)}$ 実現可能であ る。実際, $300^{\circ} \mathrm{C}$ の基板温度で伝導度は $\mathrm{p}$ 型, $\mathrm{n}$ 型とも に $10^{-10} \sim 10^{-2} \Omega^{-1} \mathrm{~cm}^{-1}$ の領域で制御されている ${ }^{16)}$ 。ボ ロン添加時の膜成長は著しく増速され且つ反応機構も気

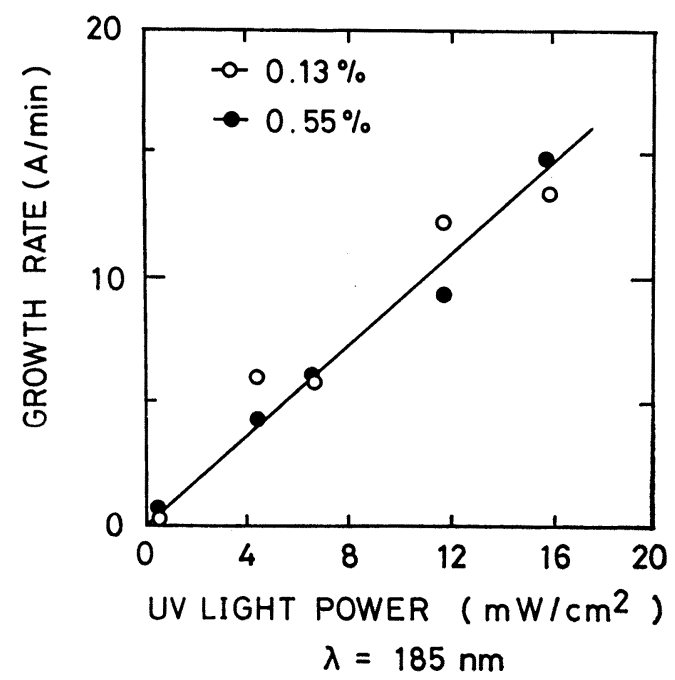

Fig. 5 Light power dependence of silicon growth rate。 


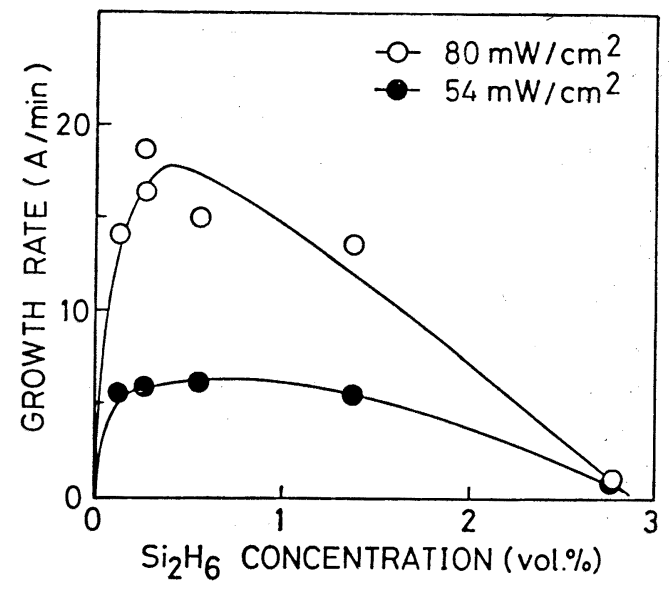

Fig. 6 Growth rate of undoped silicon films against $\mathrm{Si}_{2} \mathrm{H}_{6}$ concentration.

相反応律速から活性化エネルギ $0.64 \mathrm{eV}$ をむつ表面反応 律速に変化している。

$\mathrm{SiO}_{2}$ 膜の光 $\mathrm{CVD}$ では, $\mathrm{O}_{2}, \mathrm{~N}_{2} \mathrm{O}$ はいずれも吸収端 が $240 \mathrm{~nm}$ であるため, $185 \mathrm{~nm} \mathrm{UV}$ 光で光分解する。

$\mathrm{N}_{2} \mathrm{O}$ を分解し $\mathrm{SiH}_{4}$ との衝突反応により $\mathrm{SiO}_{2}$ が作られ たが，乙の場合 $\mathrm{SiH}_{4}$ は光分解していない20)。また 40 $\mathrm{MW} / \mathrm{cm}^{2}$ の $\mathrm{ArF}$ エキシマレーザ光を $\mathrm{SiH}_{4}+\mathrm{N}_{2} \mathrm{O}$ 系に 照射すると, $\mathrm{SiH}_{4}$ も 2 光子吸収で解離し, $\mathrm{SiO}_{2}$ が得ら れている ${ }^{211}$ 。筆者らは $\mathrm{Si}_{2} \mathrm{H}_{6}+\mathrm{O}_{2}$ 混合ガスを $185 \mathrm{~nm}$ 光 で直接光分解し $\mathrm{SiO}_{2}$ 膜を形成した ${ }^{22)}$ 。Fig. 7 に示すよ うに, $300^{\circ} \mathrm{C}$ 以下では表面反応律速であり, 活性化エネ ルギは熱 CVD の場合の $0.96 \mathrm{eV}$ から $0.53 \mathrm{eV}$ と大幅

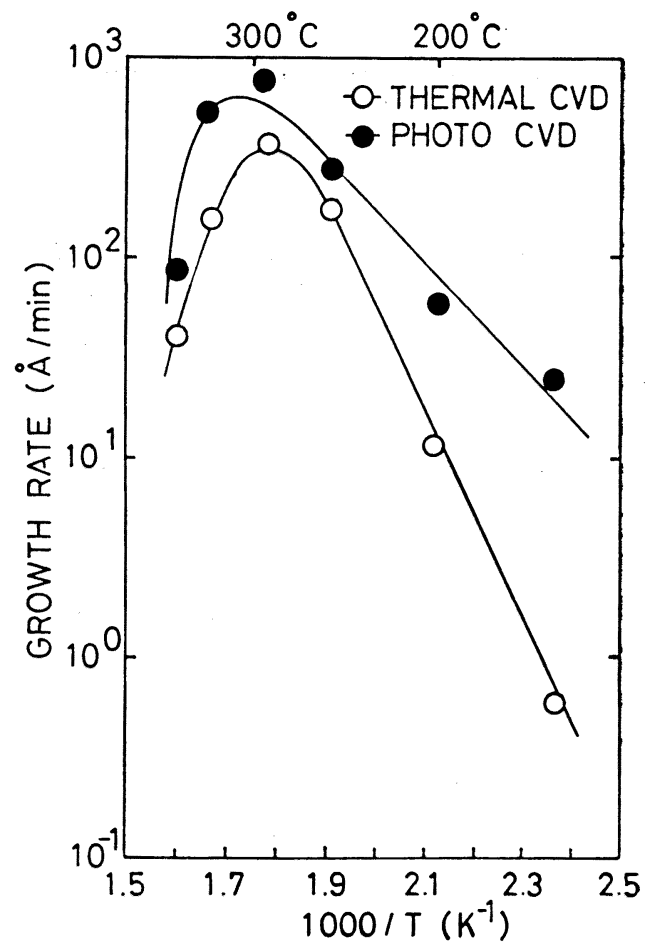

Fig. 7 Growth rate of photo-CVD and thermal CVD $\mathrm{SiO}_{2}$ films from $\mathrm{Si}_{2} \mathrm{H}_{6}+\mathrm{C}_{2}$ as a function of reciprocal substrate temperature.

に低下している。低温光照射による酸化膜形成速度の著 しい増大は, 光照射部分だけへの選択的な酸化膜形成の 可能性を示している。

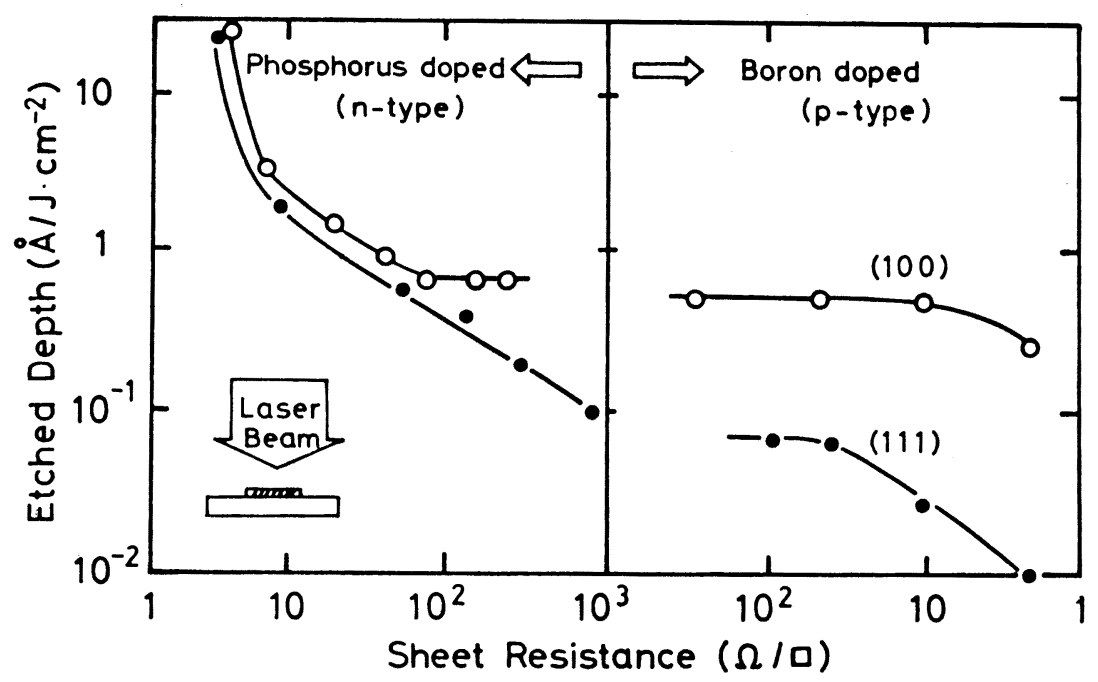

Fig. 8 Silicon etching rate vs sheet resistance of Si substrate. Horizontal axis (left to right) corresponds to the shift of the Fermi level from the conduction band edge to the valence band: 
$\mathrm{SiO}_{2}$ 膜の構造を赤外吸収スペクトルで調べると, 熱酸 化膜とちがって $880 \mathrm{~cm}^{-1}$ に $\mathrm{SiO}_{2}$ 中の欠陥に依ると思 われる吸収が存在するが, 基板温度を $300^{\circ} \mathrm{C}$ 程度まで上 げると殆んど消失し, 膜中の固定電荷密度も $2 \sim 3 \times 10^{11}$ $\mathrm{cm}^{-2}$ に低下する。

\section{2. 光化学エッチング}

$\mathrm{Si}$ のエッチングは $\mathrm{Cl}_{2}$ ガス中で, $\mathrm{Ar}$ イオンレーザ, $\mathrm{Xe}-\mathrm{Hg}$ ランプ, 又は $\mathrm{XeCl}$ エキシマレーザ $(308 \mathrm{~nm})$ 照射下で行われた 23-25)。Arikado ら ${ }^{25)}$ は, $\mathrm{Si}^{2} / \mathrm{Cl}_{2}$ 系の 光化学エッチングの機構が $\mathrm{Si}$ 中の電子の関与した表面 光化学反応であることを示した (Fig. 8)。つまり $\mathrm{Si}$ 中 の電子濃度の減少がエッチング速度の低下をもたらして いる。乙れを, Si から Cl ラジカルへの電子のトンネル に伴う $\mathrm{Cl}^{-}$の形成と引きつづく $\mathrm{Si}^{+}$との間の反応でエ
ッチングが起るととによるとして説明した。半導体プロ セスに扔いて $\mathrm{Si}$ のエッチングと並んで $\mathrm{SiO}_{2}$ のエッチ ングあ重要であるが, これまでの研究は少く, $\mathrm{Cl}_{2}$ ガス による集光 $\mathrm{Ar} レ$ レ゙光エッチング ${ }^{26)}, \mathrm{CF}_{3} \mathrm{Br}$ による 集光 $\mathrm{CO}_{2}$ レーザ光エッチング27などが試みられている。 筆者らは, $\mathrm{SiO}_{2}$ を $\mathrm{NF}_{3}+\mathrm{H}_{2}$ 混合ガス中で $\mathrm{ArF}$ エキシ マレーザ光照射によってエッチングしその反応メカニズ ムを in-situ X 線光電子分光 (XPS) 及び in-situ 赤外分 光 (IR) によって調べた ${ }^{28)}$ 。

Fig. 9 は in-situ XPS が可能な反応装置を示す。 $\mathrm{ArF}$ エキシマレーザ $(193 \mathrm{~nm})$ のパルス出力は $40 \mathrm{~mJ} /$ shot, パルス繰返し周波数は $80 \mathrm{~Hz}$ である。光エッチン グ後のサンプル表面を大気にさらすととなく XPS 湘定 室に移すことができるようになっている。これによって

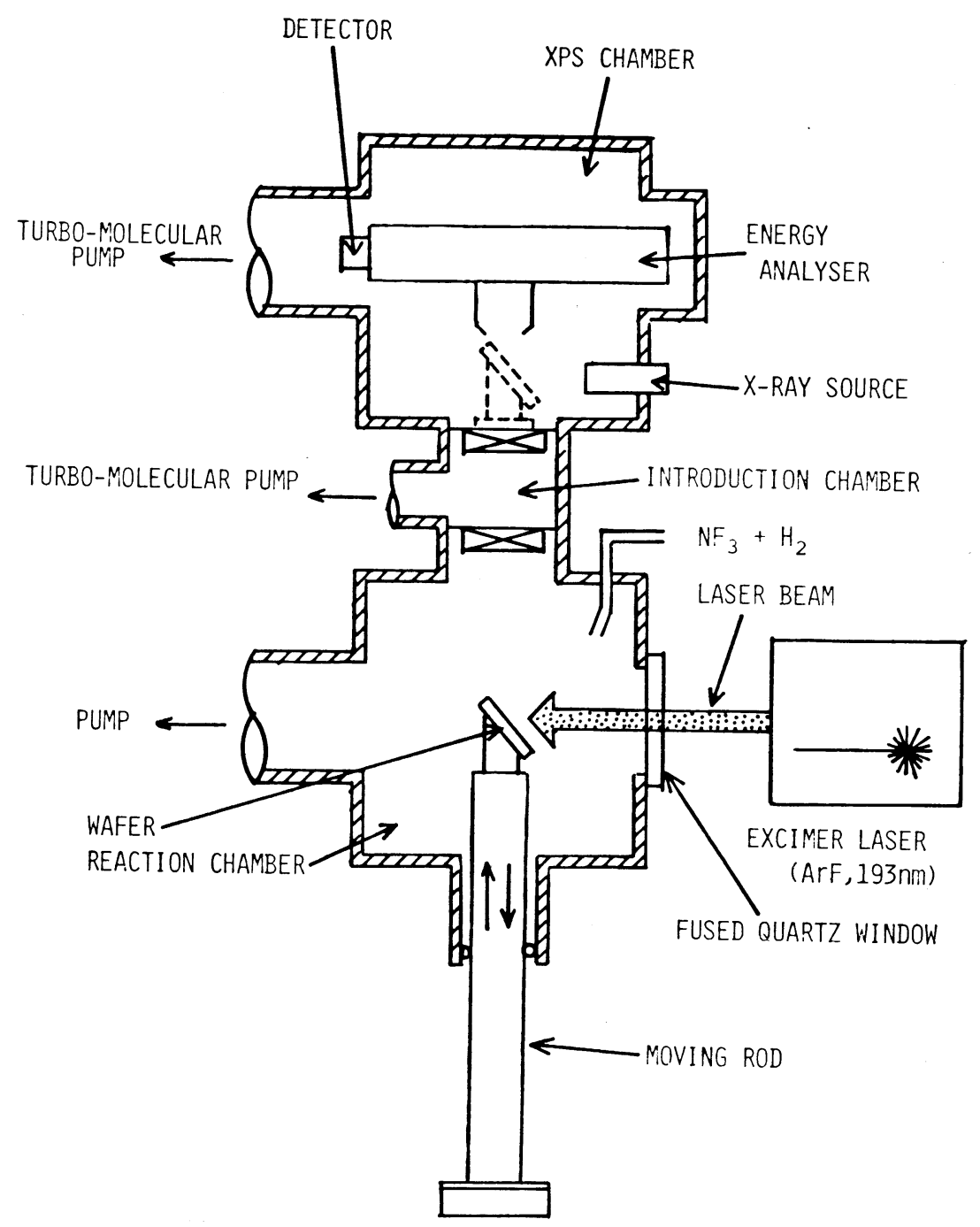

Fig. 9 Schematic diagram of photochemical etching apparatus for in-situ XPS, 
エッチング表面の化学結合状態の分析が可能である。

低圧 $\left(\mathrm{NF}_{3}=480 \mathrm{P}, \mathrm{H}_{2}=20 \mathrm{~Pa}\right)$ でのレーザ光照射 (1 分間) と引きつづく大気圧 $\left(\mathrm{NF}_{3}=9.8 \times 10^{4} \mathrm{P}_{\mathrm{a}}, \mathrm{H}_{2}=2.6\right.$ $\left.\times 10^{3} \mathrm{P}_{\mathrm{a}}\right)$ でのレーザ光照射を組み合わせた場合のエッチ ング速度は大きく, 低圧での照射のみ, 又は大気圧での 照射のみではエッチングレートは小さい。光入射は基板 に水平又は垂直 (Fig. 3(a)，（b)) のよ゙ちらでも起り， 気相中で光化学分解によって作られたラジカルによる等 方性のエッチングである。Fig. 10 は低圧照射につづい て大気圧照射を行ったときの $\mathrm{SiO}_{2}$ 表面の XPS スペク トルの時間的変化を示している。低圧照射を行うと $\mathrm{N}_{1 \mathrm{~s}}$
及び $F_{1 s}$ の信号強度が増加し，引続く大気圧照射によっ て信号強度は更に増加する。同時に $\mathrm{N}_{1 \mathrm{~s}}$ 信号は高エネル ギ側へ， $F_{1 s}$ 信号は低エネルギ側へシフトする。てれは 次のように説明できる。低圧処理を施した場合，初期の 段階で観測される $\mathrm{N}_{1 \mathrm{~s}}$ 及び $\mathrm{F}_{1 \mathrm{~s}}$ 信号は気相中で $\mathrm{NF}_{3}$ が 光分解して生じた窒素及びフッ素ラジカルが $\mathrm{SiO}_{2}$ 表面 に吸着した結果生ずる。引続く大気圧処理によっててれ らのラジカルは $\mathrm{SiO}_{2}$ と反応して表面に NO 及び $\mathrm{SiF}$ 結 合を形成する。F の電気陰性度は Si のそれに比べ大き いため F は負に帯電する。一方 Nの電気陰性度はOのそ れより小さいためNは正に帯電する。との結果 $\mathrm{F}_{1 \mathrm{~s}}$ 信号

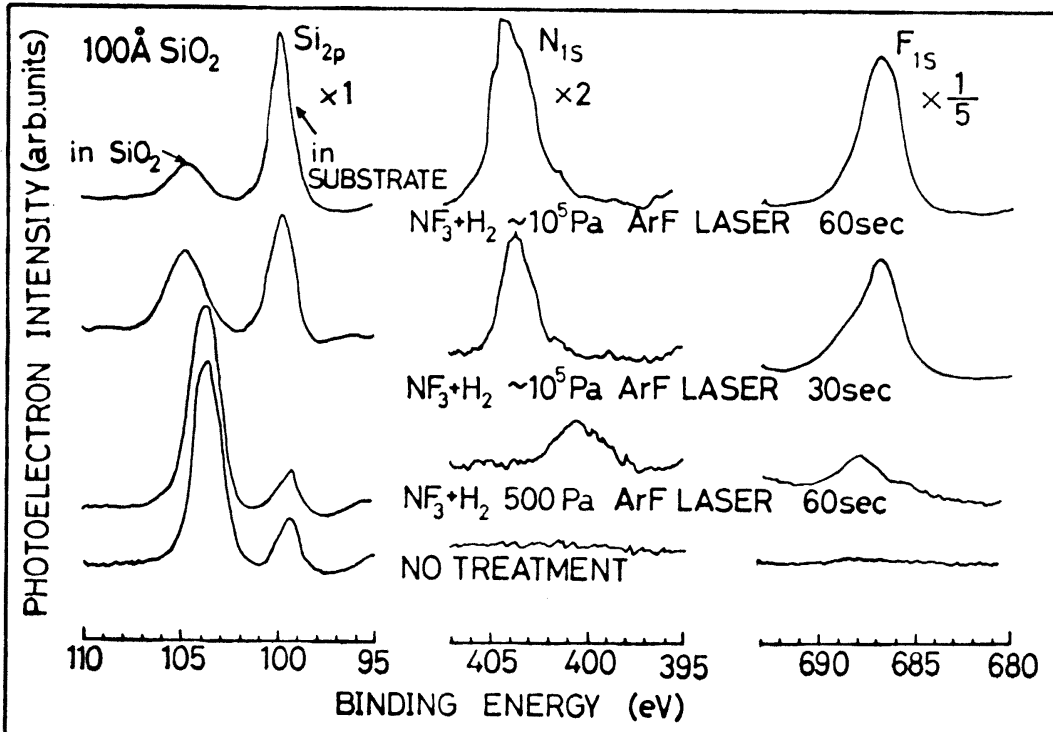

Fig. 10 XPS spectra for the sample photochemically etched in the atmospheric pressure after low pressure pretreatment:

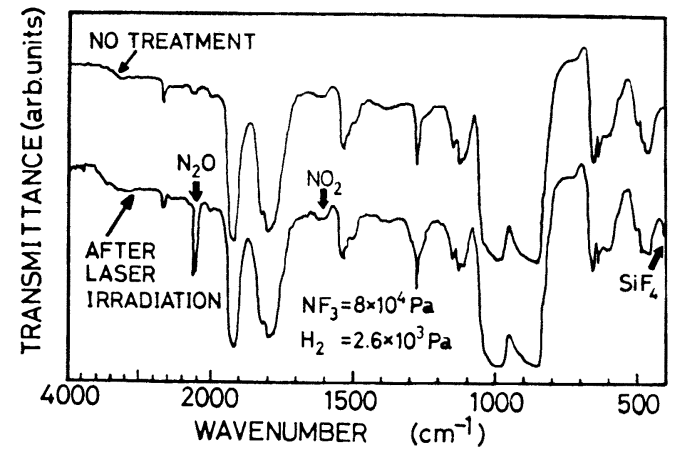

(a)

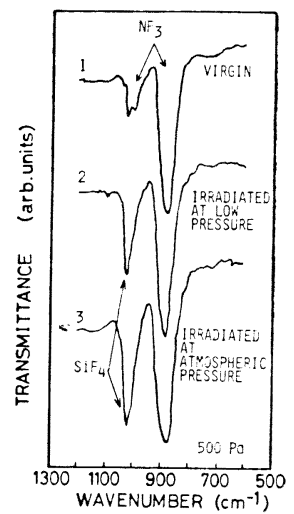

(b)

Fig. 11 The infrared spectra of $\mathrm{NF}_{3}+\mathrm{H}_{2}$ gas mixture before and after laser irradiation at atmospheric pressure (a) and low pressure (b). 
は低エネルギ側へ， $\mathrm{N}_{1 \mathrm{~s}}$ 信号は高エネルギ側へ chemical シフトするととになる。

常圧処理において, $\mathrm{SiO}_{2}$ 中の $\mathrm{Si}_{2 \mathrm{p}}$ 信号の高エネルギ 側へのシフトがみられるが，てれはエッチングの進行に 伴う $\mathrm{SiF}_{4}$ 分子の形成が $\mathrm{SiO}_{2}$ 表面で起っていることを 示している。

一方大気圧処理のみでは, ガス分子の平均自由行程が 短く基底状態にある未分解分子の衝突による脱励起がひ

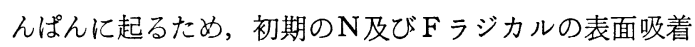
が起りにくく, その後の表面反応屯進行しにくいと考え られる。これらのととより, 低圧前処理の役割は, $\mathrm{SiO}_{2}$ の表面をラジカルによって活性化し，その後の大気圧処 理によるエッチングの進行を促進することにあると考え られる。Fig. 11 はレーザ光照射によってガス中に生じ たエッチングの生成物をin-situ IR によって調べた結果 である。(a)四に示すように $\mathrm{NO}_{2}$ 及び $\mathrm{SiF}_{4}$ が気相中 に生成されていることがわかる。また(b)図 3 のスペク トルは (a )の反応ガスを低压にして測定したもので $\mathrm{SiF}_{4}$ の生成がより明確に示されている。てれより $\mathrm{SiO}_{2}$ の光 化学エッチングはオーバーオールには次の反応で表わさ れることが分る。

$$
\mathrm{SiO}_{2}+\mathrm{NF}_{3}+\mathrm{H}_{2} \stackrel{h \nu}{\longrightarrow} \mathrm{SiF}_{4}+\mathrm{NO}_{2}+\mathrm{N}_{2} \mathrm{O}+\mathrm{HF}
$$

但し HF は IR の測定で直接観測されていないが, $\mathrm{NF}_{3}$ と $\mathrm{H}_{2}$ の高い反応性を考えると存在するあのと考え られる。

\section{6. 今後の展望}

プラズマプロセスは反忘系としては極めて効率の良い システムであり, 今後共低温プロセスとして各方面で使 われるだろう。プラズマ反応装置は既に完成された技術 のようにみえるが，実際には，放電電極間の電位を制御 する新しい方法もごく最近に開発された ${ }^{29)}$ 。また放電に よって作られるラジカルのみをビームとして超高真空中 により出し, 単結晶の成長を行ったり ${ }^{30)}$, 固体表面の無 損傷エッチングを行ったりするととができる。プラズマ 中で起る化学反応については, 十分に研究のメスが入っ ているとは言えない。プラズマプロセスは無限の可能性 をむっている潜在的ポテンシャルの高い技術であるとと を強調したい。

光励起プロセスはこて数年急速に注目をあび始めた。 これは高出力の紫外線レーザ（エキシマレーザ）が容易 に入手できるようになったととが大きな駆動力となって いると思わ机る。光化学プロセスを, 集積回路技術に持 ち込もうとする努力は, サブミクロンデバイスの時代に 向けて本格化すると思われ，幾多の新技術の登場が期待
される。光化学反応を用いる結晶成長技術の開発も新し い成果が得られはじめており ${ }^{31,32)}$, 成長機構の解明を含 めて将来の発展が楽しみな分野である。光化学反応は無 機物質の加工や合成のみならず, 有機薄膜の合成や表面 改質などにあ威力を発揮すると考えられ新しい化学プロ セスの開発む検討されている。光励起プロセスは, プラ ズマプロセスに較べれば, 現状ではまだ研究段階の技術 という色彩は強いが，プロセス技術としての有効性の証 明はこの数年のうちに大きく進展すると思われる。

\section{文献}

1）菅野卓雄編著：半導体プラズマプロセス技術 (1980) 産業図書.

2)「電子材料」編集部編：超 LSI 時代のプラズマ化 学 (1983) 工業調查会.

3) T. J. Chuang: Surface Science Reports 3 (1983) p. 1.

4) Semiconductor and Semimetals Vol. 21 Part A, edited by J.I. Pankove (Academic Press, Inc., 1984) chapter $2,8$.

5) 半導体研究第 19 巻 (工業調査会, 1982 年) 第 8 章.

6）田中一宜編著：アモルファス半導体の基礎 (1982) オーム社.

7) K. Euke, H. Dimigen and H. Hübsch : Appl. Phys. Lett. 36 (1980) 291.

8) 広瀬, 浜崎 : 応用物理, 52 (1983) 657.

9) F. J. Kampas and R. W. Griffith: Appl. Phys. Lett. 39 (1981) 407.

10) M. Hirose: Jpn. J. Appl. Phys. 21 (1982) Suppl. 21-1, 275.

11) M. Dohjo, M. Hirose and Y. Osaka : Proc. 1982 Dry Process Symp. (IEE of Japan, 1982) p. 17.

12) Y. Horiike and M. Shibagaki: Jpn. J. Appl. Phys. Suppl. 45 (1976) 13.

13) H.F. Winters, J.W. Coburm and E. Kay: J. Appl. Phys. 48 (1977) 4973.

14）薄膜 131 委員会研究資料（日本学術振興会, 1984 年 9 月21日) p. 17 33.

15) Y. Mishima, M. Hirose, Y. Osaka, K. Nagamine, Y. Ashida, N. Kitagawa and K. Isogaya: Jpn. J. Appl. Phys. 22 (1983) L 46.

16) Y. Mishima, M. Hirose, Y. Osaka and Y. Ashida: J. Appl. Phys. 55 (1984) in press.

17) G. G. A. Perkins and F.W. Lampe: J. Am. Chem. Soc. 102 (1980) 3764.

18) J. H. Clark and R.G. Anderson: Appl. Phys. Lett. 32 (1978) 46.

19) F. Feher : in Forshungsber. Landes NordrheinWestfalen, No. 2632 (1977) p. 11.

20) J. W. Peters: IEDM 81 (1981) 240.

21) P. K. Boyer, G. A. Roche, W.H. Ritchie and G. J. Collins: Appl. Phys. Lett. 40 (1982) 716.

22) Y. Mishima, M. Hirose and Y. Osaka: J. Appl. Phys. 55 (1984) 1234. 
23) D. J. Ehrlich, R. M. Osgood, Jr. and T.F. Deutsch : Appl. Phys. Lett. 38 (1981) 1018.

24) M. Sekine, H. Okano and Y. Horiike : Proc. of the 5th Symp. on Dry Processes (1983) p. 97.

25) T. Arikado, M. Sekine, H. Okano and Y. Horiike : to be published in Proc. of Material Research Society Meeting (Boston 1983).

26) T. J. Chuang: IBM J. Res. Develop. 26 (1982) 145.

27) J. I. Steinfeld, T. G. Anderson, C. Reiser, D. R. Denison, L. D. Hartsough and J. R. Hollahan: J. Electrochem. Soc. 127 (1980) 514.

28) S. Yokoyama, Y. Yamakage and M. Hirose: Extended Abstracts of the 16th Intern. Conf. on Solid State Devices and Materials (Kobe,
1984) p. 451.

29) T. Hamasaki, M. Ueda, A. Chayahara, M. Hirose and Y. Osaka: Appl. Phys. Lett. 44 (1984) 1049.

30) S. Miyazaki, H. Hirata and M. Hirose : Extended Abstracts of the 16th Intern. Conf. on Solid State Devices and Materials (Kobe, 1984) p. 447.

31) J. Nishizawa and Y. Kokubu: Extended Abstracts of the 16th Intern. Conf. on Solid State Devices and Materials (Kobe, 1984) p.1.

32) T. Yamazaki, T. Ito and H. Ishikawa : 1984 Symposium on VISI Technology (San Diego, 1984) p. 56. 